\title{
Study on the Development Path of Agricultural New Format under the Background of Supply Side Reform
}

\author{
Yu He \\ Sichuan Agricultural University, Chengdu, Sichuan, 611130
}

Keywords: Agriculture; Supply Side Reform; New Format

\begin{abstract}
In the new era of socialism with Chinese characteristics, the issue of "agriculture, rural areas and farmers" is still the top priority of the work. How can the development of new agricultural forms in this context be an effective help to promote the structural reform of agricultural supply side. This paper analyzes the existing problems in the development of new forms of agriculture, finds out the influencing factors, and provides effective path suggestions from the aspects of land, science and technology, finance, subject (person) and so on, so as to realize the sustainable development of new agricultural forms.
\end{abstract}

\section{Introduction}

In 2015, the central authorities put forward a major step in structural reform of the supply side. 2017 Central Document No. 1 established the "three rural" work in the future for a period of time to speed up the reform of agricultural supply side to ensure effective supply, increase farmers' income, protect the ecological environment, and effectively play the multi-functional role of agriculture, accelerate the transformation of agricultural and rural industries, The development of new industries and new formats. This is consistent with the law of the development of the world's agricultural and rural economy, but also an important contribution to the agricultural economy of the Chinese characteristics of the socialist market.

\section{The existence of the problem}

The conditions of the infrastructure directly affect the ability of the new industry to create externalities. At present, the agricultural-related industries have poor infrastructure conditions and seriously hampered the development of new industries. In the past, the village road is limited by the financial resources and the terrain conditions. The design specifications are only $3.5 \mathrm{~m}$ wide. The plains of the plains can still be configured with hard roads. In the basin and deep hill area, the rural roads are not suitable for the new construction. The development of the three rural industry requirements of the times, the car in the process of rural roads in the process of accidental car accidents, due to the wrong car led to the situation into the side of the trench. Road bearing capacity is poor, the conservation situation is equally worrying, most areas of the road can not afford to pass through the cart, only by setting the limit bar and other ways to limit the passage of the cart, and because maintenance is not timely lead to traffic problems are not uncommon. Scenic spots, attractions facilities are not perfect. Part of the region to the development of rural tourism as the starting point to lead the regional economy, but ignore the scenic spots supporting infrastructure construction, resulting in scenic spot quality and efficiency of unsatisfactory. Xinjin Bamboo Garden Forest Park, location and landscape advantages are good, but the scenic parking lot is small, less toilet, it is difficult to adapt to the needs of scenic development.

There are obvious differences in the characteristics of various new industries, lack of scientific and technological support is different from the specific performance: due to the weak agricultural information infrastructure, local characteristics of the fruit and fruit industry producers difficult to obtain timely product demand information, resulting in product price instability, inventory backlog, industry Poor resistance to risk. Tourism industry, tourism industry, rural cultural industry and other 
rural tourism industry on the network resource utilization is not high, tourism activities, network promotion and promotion is not in place, in the use of new media marketing means relatively backward; due to the lack of tourist demand early warning system, part of the scenic area Often appear "overload" reception phenomenon, seriously reduce the quality of tourism. "Internet +" industry, the facilities of agricultural demonstration park water and fertilizer integration technology applications to be improved; rural electricity business development problems: agricultural products online rate is not high, the quality difference is large, low level of commercialization, and large-scale e-commerce requirements gap In addition, a wide range of agricultural products, production units are small, in the handling, preservation, transportation is more difficult to increase the logistics links difficult. At present, lack of scientific and technological support led to low technological content of the new format, seriously restricting the development of new industries.

At present, the phenomenon of homogenization of agricultural new industry is more serious, there are different degrees of homogenization between regional and regional and regional, local characteristics of the industry is not prominent, the lack of reasonable planning, trade between the vicious competition. In recent years, fruit market market is good, most places follow the trend of planting, but ignored the market demand, the price does not increase, farmers increase difficulties. Tourism, rural houses, farm music and resort hotels and other industries are also homogeneous phenomenon. With the rise of rural tourism, all kinds of flowers and flowers festival has become a lot of areas to attract tourists gimmicks, cauliflower, peach blossom festival and pear festival, such as the rise, but mostly lack of characteristics, monotony; all kinds of b \& B is also vigorously Bed and breakfast to have mountains and water, the plain area of the room heavier moisture, the lack of conditions for the development of bed and breakfast.

\section{The influencing factors}

Basic conditions difficult to adapt to the new industry development, the main reason is that agricultural and rural planning is not in place. Road traffic, $3.5 \mathrm{~m}$ wide rural road is no longer suitable for industrial development needs, the relevant road planning need to be modified. Scenic spots construction, some scenic planning is unreasonable, the lack of supporting parking lot, toilet and other public infrastructure design, it is difficult to meet the scenic development; or although planning, but the planning is not fully demonstrated, involving land consolidation, facilities and other aspects , Work more difficult to carry out, resulting in planning difficult to implement. In addition, some areas of the development of the industry to develop a plan, but ignoring the synchronization of supporting facilities construction planning, leading to scientific planning deficiencies, bound the development of new industry formats.

Agriculture, agriculture, science and technology supply is difficult to adapt to the individual needs of new industries, agricultural research results and practice applications out of line: on the one hand, the producers of the Agricultural science and technology services show a strong demand for demand, on the other hand, after receiving the agricultural science and technology services, only a small number of producers can immediately put the new agricultural technology into practice, "shouting loud, echoing little" phenomenon is common. Agricultural science and technology supply and practical application between the insurmountable gap, the new format technology to enhance the space larger.

There is a homogenization phenomenon in the development of rural new forms, mainly due to the irrational allocation of rural resources, including land resources, human resources and financial resources. As a result of the interests of the local government and positioning, blindly follow the trend of the development of the current hot products, not according to their own characteristics of rational allocation of resources, resulting in the new state of homogenization of the phenomenon.

The Choice of Land Resources in New Industry. Land use structure and direction of the new industry will have an impact on the industrial location, the choice of agricultural varieties need to consider the suitability of land, the size of the land area will affect the scale of industrial development, land quality and intensive use of land will be on land use The impact of the realization of efficiency, and ultimately the impact of industrial efficiency, the optimal allocation of 
rural construction land will also affect the rural houses, farm music and other new forms of choice.

The Choice of Human Resource Allocation to New Industry. The unique analysis of the development of the industry will affect the industrial decision-making and follow-up development of the new industry. The allocation of labor resources will also affect the development of new forms. The people should be placed in the most favorable way to play Advantages of the job, such as the development of fruits and vegetables, tea and other industries need a larger labor force, rural electricity providers need to high knowledge, high-tech talent, these are managers choose the industry will consider the factors.

The Choice of Financial Resources in New Industry. The development of an industry is the most important is to have financial security, and industrial development special funds, agriculture-related loans, financial subsidies, tax incentives, financial support and other policies, is to attract industrial and commercial capital to the local development and selection of important factors, Policy tilt will guide the choice of business-oriented enterprises, resulting in enterprises have flooded the government subsidies, financial support efforts of large industries.

\section{Countermeasures and suggestions}

To strengthen the road maintenance and maintenance, to enhance the road carrying capacity; to encourage the community through a variety of ways to participate in the promotion of rural road development, broaden the road construction funds to expand the road construction funds, to expand the road construction funds Source approach, to protect the road planning as soon as possible landing. Fully demonstrate the scenic area construction planning program, improve the scenic area tourism sign plate set, star tourism toilet construction, ecological parking lot to build tourism support, comprehensively enhance the tourism facilities grade, reinforce the tourism industry and other new development basis. Improve the modern agriculture, facilities, agriculture and other new development and construction planning, give full consideration to the main body of the industry and supporting the support of the close ties to enhance the feasibility of industrial development planning and operability, boost the orderly development of the new industry.

Increase investment in rural infrastructure, health care, education and culture, entertainment and leisure, strengthen the introduction of new talents in rural areas, optimize the benefits and benefits of new forms of talent, while the establishment of urban and rural non-discriminatory human resources market, the elimination of urban local human resources The employment of discrimination, to attract a large number of knowledge, knowledge, will operate the talent to rural employment; to strengthen the cultivation of professional farmers, certification, support work, fundamentally the liberation of farmers 'ideas, improve farmers' subjective initiative, establish and improve the new farmer cultivation system, Pay attention to play the power of young farmers, give full play to vocational schools, rural modern distance education network and agricultural technology promotion training base role, cultivate food cultivation talent, grain management personnel, grain intensive processing personnel, promote farmers to adapt to modern agricultural development needs and agricultural science and technology Progress, changes in agricultural market demand; the establishment of rural human resources information base and human resources mobile service agencies, strengthen the local information network construction, give full play to the role of information technology in human resources allocation.

At present, we should study the policies and measures to support the development and development of new industries in rural areas, and clearly support the overall policy requirements, key content, support policies and work. Support the introduction of large-scale electric business enterprises, star hotels, agricultural industrialization leading enterprises to grow and develop new formats, cultivate new forms of farm farms, farmer cooperatives, rural hotels and other new business entities. Innovation and financial use of funds to allow all localities to take the award generation, the first to build after the financial discount interest, financial funds and other ways to support the development of new formats. Promote PPP, all the investment and other investment models, expand the scope of credit collateral, innovative tickets, warehouse receipts, fund shares and other ways. To determine a number of provincial agricultural and rural new model counties 
(cities, districts), assessed after the acceptance of financial subsidies.

\section{References}

[1] Jiang Weiguo. China's agricultural supply side of the structural reform of the study of modern economy, 2016 (4): 15 -19

[2] Jiang Xiaoguo, Hong Gongxiang. Agricultural supply side reform: background, path and international experience. Modern economic discussion 2016 (10): 35- 39

[3] Jiang Yan. Path Innovation of Rural Land Capitalization Reform. Journal of Northwest A \& F University (Social Science Edition), 2015 (6): 25 -31

[4] Pei Xiaoqiu. Standing on the people's position to speed up the improvement of the socialist market economy [J]. Theoretical exploration .2014, (5): 88. 